\title{
Tensile Adhesion Strength of Biomass Ash Deposits: Effect of the Temperature Gradient and Ash Chemistry
}

Laxminarayan, Yashasvi; Nair, Akhilesh Balachandran; Jensen, Peter Arendt; Wu, Hao; Jappe Frandsen, Flemming; Sander, Bo; Glarborg, Peter

Published in:

Energy and Fuels

Link to article, DOI:

10.1021/acs.energyfuels.7b03114

Publication date:

2018

Document Version

Peer reviewed version

Link back to DTU Orbit

Citation (APA):

Laxminarayan, Y., Nair, A. B., Jensen, P. A., Wu, H., Jappe Frandsen, F., Sander, B., \& Glarborg, P. (2018).

Tensile Adhesion Strength of Biomass Ash Deposits: Effect of the Temperature Gradient and Ash Chemistry.

Energy and Fuels, 32(4), 4432-4441. https://doi.org/10.1021/acs.energyfuels.7b03114

\section{General rights}

Copyright and moral rights for the publications made accessible in the public portal are retained by the authors and/or other copyright owners and it is a condition of accessing publications that users recognise and abide by the legal requirements associated with these rights.

- Users may download and print one copy of any publication from the public portal for the purpose of private study or research.

- You may not further distribute the material or use it for any profit-making activity or commercial gain

- You may freely distribute the URL identifying the publication in the public portal 


\section{Tensile Adhesion Strength of Biomass Ash}

\section{Deposits- Effect of Temperature Gradient and Ash}

\section{Chemistry}

Yashasvi Laxminarayan ${ }^{*}{ }^{\dagger}$, Akhilesh Balachandran Nair ${ }^{\dagger}$, Peter Arendt Jensen ${ }^{\dagger}, \mathrm{Hao} \mathrm{Wu}^{\dagger}$, Flemming Jappe Frandsen ${ }^{\dagger}$, Bo Sander ${ }^{\S}$, Peter Glarborg ${ }^{\dagger}$

$\dagger$ Department of Chemical and Biochemical Engineering, Technical University of Denmark, Søltofts Plads 229, 2800 Kgs. Lyngby, Denmark

$\S$ Ørsted Bioenergy \& Thermal Power A/S, Kraftsværksvej 53, Skærbæk, DK-7000, Fredericia, Denmark

Keywords: biomass, ash, deposit, adhesion, shedding, sintering, corrosion, temperature gradient, t-test

*Corresponding author e-mail id: ylax@kt.dtu.dk

Abstract: Replacing coal with biomass in power plants is a viable option for reducing net $\mathrm{CO}_{2}$ emissions and combating climate change. However, biomass combustion in boilers may exacerbate problems related to ash deposition and corrosion, demanding effective deposit removal. The tensile adhesion strength of model biomass ash deposits, containing mixtures of $\mathrm{KCl}, \mathrm{K}_{2} \mathrm{SO}_{4}$, $\mathrm{CaO}, \mathrm{CaSO}_{4}$, and $\mathrm{K}_{2} \mathrm{Si}_{4} \mathrm{O}_{9}$, has been investigated in this study. The deposits were prepared on 
superheater steel tubes, and sintered in an oven. The superheater steel tube was cooled by air, incorporating a temperature gradient across the deposits. After sintering, the deposits were removed using an electrically controlled arm, and the corresponding tensile adhesion strength was measured. The effects of flue gas temperature $\left(500-700^{\circ} \mathrm{C}\right)$, steel surface temperature $(500-650$ ${ }^{\circ} \mathrm{C}$ ) and deposit composition were investigated. The results revealed that increasing the flue gas temperature, as well as the steel surface temperature, led to a sharp increase in the tensile adhesion strength of the model deposits. The sharp increase was typically observed near the melting temperature (or deformation temperature) of the investigated model deposits. Furthermore, migration of molten/vapor species from the outer layer of the deposit to the deposit-tube interface, causing liquid state sintering, was observed at high flue gas temperatures, leading to an increase in the tensile adhesion strength. Varying the ash chemistry of the model deposits revealed that the melt fraction of the deposit was highly influential in determining the deposit adhesion strength. Addition of compounds which increased the melt fraction of the deposit increased the tensile adhesion strength, whereas addition of inert compounds with a high melting point, such as $\mathrm{CaO}$, decreased the tensile adhesion strength. Moreover, the results suggested that the adhesion strength of the deposits was influenced by the corrosion occurring at the deposit-tube interface.

\section{Introduction}

Following the Paris Agreement at $\mathrm{COP} 21,{ }^{1}$ global efforts to mitigate climate change have accelerated. Being a $\mathrm{CO}_{2}$ neutral fuel, biomass can potentially replace coal for providing flexible electricity and heat production. Globally, the supply of biomass for energy has been growing at $2.5 \%$ every year since 2010 , with bioenergy contributing $10.5 \%$ of the global primary energy

consumption. ${ }^{2}$ With Denmark aiming to replace coal with biomass in pulverized fuel power plants by $2030,{ }^{3}$ biomass-firing and cofiring are gaining increased importance. However, biomass-fired 
boilers encounter numerous operational challenges, several of which are related to the critical volatile ash forming elements, such as $\mathrm{K}$ and $\mathrm{Cl}$, causing severe ash deposition and corrosion on boiler surfaces. ${ }^{4,5}$ Deposit formation in boilers may occur through several mechanisms, including diffusion and condensation of vapors, thermophoresis, convective diffusion, and inertial impaction. ${ }^{6,7}$ Ash deposition on boiler surfaces hinders heat transfer to the steam cycle, thereby reducing boiler efficiency. ${ }^{8}$ Moreover, ash deposition may completely block the flue gas channels in severe cases, resulting in expensive boiler shutdowns. Therefore, timely and effective deposit removal is essential for maximizing boiler efficiency and availability.

Shedding of ash deposits in boilers may occur naturally, without any operational influence, or may be induced artificially (e.g., using soot-blowing, or load changes). Deposit shedding may occur through several mechanisms, including erosion, debonding, molten slag flow, and thermal and mechanical stresses within the deposits. ${ }^{5}$ Erosion occurs when sharp-edged fly ash particles collide with non-molten deposits, resulting in deposit removal through chipping or repeated deformation. Debonding occurs when the generated stress (e.g., by soot-blowing, or due to the weight of the deposit) exceeds the adhesion strength at the deposit-tube interface, resulting in deposit removal from the tube surface. If the temperature of the outer layer of the deposit is sufficiently high for the formation of low-viscosity slags, molten phases may flow off the deposit. Thermal shocks caused by temperature changes in the boiler may induce deposit shedding due to differences among the thermal expansion coefficients of the tube, the corrosion layer, and the deposit. Full-scale investigations have identified that debonding is the dominant mechanism for deposit shedding in suspension-fired biomass boilers. ${ }^{9}$ Hence, quantification of the adhesion strength of ash deposits is essential for understanding deposit shedding, and for optimizing artificial removal of deposits (e.g., by soot-blowing) in boilers. Since soot-blowing in boilers may 
produce both lateral (lift) and longitudinal (drag) forces on deposits, ${ }^{10}$ it is important to quantify both the shear and the tensile adhesion strength of ash deposits.

The adhesion strength of coal ash deposits ${ }^{11-13}$ and deposits in kraft recovery boilers ${ }^{10}$ has been investigated in previous studies, while a few studies have quantified the compression and bend strength of ash deposits. ${ }^{14-17}$ The authors have previously investigated the shear adhesion strength of biomass ash deposits to superheater steel tubes, describing the influence of sintering temperature, sintering time, deposit composition, thermal shocks on the deposit, and steel type ${ }^{18}$ However, the majority of studies investigating the adhesion strength of ash deposits have been performed under isothermal conditions. While a few studies have incorporated temperature gradients across the deposit layer to understand the effect of corrosion, ${ }^{19-21}$ the effect of temperature gradients on the adhesion strength of ash deposits has not been investigated previously, to the best of the authors' knowledge.

The temperature difference across deposits in full-scale boilers can be greater than $200{ }^{\circ} \mathrm{C} .{ }^{19,22}$ Previous studies have indicated that the physical and chemical properties of the deposit may be influenced by the presence of a temperature gradient across the deposit. ${ }^{19,22}$ Differences in temperature across the deposit may cause variations in temperature dependent sintering, and vaporization and condensations of alkali and chlorine rich species within the deposit. Furthermore, the Soret effect may be observed, where a concentration gradient across the deposit is induced by a temperature gradient. ${ }^{23}$ Therefore, incorporation of a temperature gradient across the deposit is essential for a realistic simulation of operational boiler conditions.

In this study, the tensile adhesion strength of salt rich biomass ash deposits was investigated, under the influence of a temperature gradient across the deposits. Artificial biomass fly ash deposits were prepared from mixtures of $\mathrm{KCl}, \mathrm{K}_{2} \mathrm{SO}_{4}, \mathrm{CaO}, \mathrm{CaSO}_{4}$, and $\mathrm{K}_{2} \mathrm{Si}_{4} \mathrm{O}_{9}$, on air-cooled 
superheater steel tubes, and sintered in an oven. After sintering, the deposits were removed using an electrically controlled arm, and the corresponding tensile adhesion strength was measured. The influence of flue gas temperature, steel surface temperature and deposit composition was investigated.

\section{Experimental Section}

\section{Materials}

Artificial biomass ash deposits were prepared using mixtures of $\mathrm{KCl}$ (Sigma Aldrich, CAS number: 7447-40-7), $\mathrm{K}_{2} \mathrm{SO}_{4}$ (Sigma Aldrich, CAS number: 7778-80-5), $\mathrm{CaO}$ (Sigma Aldrich, CAS number: 1305-78-8), $\mathrm{CaSO}_{4}$ (Alfa Aesar, CAS number: 7778-18-9), and $\mathrm{K}_{2} \mathrm{Si}_{4} \mathrm{O}_{9}$ (Alfa Aesar, CAS number: 1312-76-1). The materials were milled and sieved individually to obtain a particle size distribution in the range $32-90 \mu \mathrm{m}$. However, it should be noted that fly ash particles in biomass boilers typically form a bimodal size distribution, containing submicron particles, as well as larger particles with sizes up to $200 \mu \mathrm{m} .{ }^{6,24}$ Accurately reproducing the typical bimodal size distribution of fly ash for the experiments is a tedious process. Therefore, a fixed particle size distribution in the range $32-90 \mu \mathrm{m}$ was adopted, for comparing the influence of ash chemistry. The materials were mixed in different combinations to create model deposits, as shown in Table 1, along with their eutectic temperature/glass transition temperature. ${ }^{25}$

Furthermore, an experiment was performed using straw fly ash obtained from the bag house filter of the grate-fired boiler in Avedøreværket unit 2., ${ }^{5,2}$ The steam cycle of the $100 \mathrm{MW}_{\text {th }}$ boiler was operated at $580{ }^{\circ} \mathrm{C}$ and 300 bar, with approximately 25 tons/h of wheat straw utilized at full load. Straw was fed to the boiler on a vibrating grate, and primary air was supplied through the grate, whereas secondary air was injected in the freeboard. ${ }^{5}$ The fly ash composition and ash 
melting analysis ${ }^{27}$ is provided in Table 2. The fly ash was rich in $\mathrm{KCl}$ and $\mathrm{K}_{2} \mathrm{SO}_{4}$, with an ash deformation temperature of $640{ }^{\circ} \mathrm{C}$, slightly lower than the eutectic temperature of the $\mathrm{KCl}-\mathrm{K}_{2} \mathrm{SO}_{4}$ system of $690^{\circ} \mathrm{C}$. The particle size distribution of the fly ash is provided in Figure 1. It should be noted that submicron particles were not detected in the investigated fly ash, probably due to agglomeration during storage.

The deposits were prepared on a superheater steel tube (TP347HFG, Salzgitter Mannesmann), with an outer diameter of $38 \mathrm{~mm}$, a thickness of $5 \mathrm{~mm}$ and a length of $200 \mathrm{~mm}$. The chemical composition of the tube can be found in previously published literature. ${ }^{18}$ TP347HFG is characterized by its high $\mathrm{Cr}, \mathrm{Mn}$ and $\mathrm{Ni}$ content. The presence of $\mathrm{Cr}$ and $\mathrm{Mn}$ in steel reduces oxide scale growth by forming Cr-Mn-spinels, ${ }^{28,29}$ improving the overall corrosion resistance,${ }^{30}$ while $\mathrm{Ni}$ deters $\mathrm{Cl}$ induced corrosion. ${ }^{31}$

Apart from hindering corrosion, preoxidation of steel tubes provides a more accurate replication of operational boiler tubes. ${ }^{32-35}$ Thermogravimetric analysis of the steel tubes at $600{ }^{\circ} \mathrm{C}$ in a previous investigation ${ }^{18}$ has indicated that the majority of the oxidation occurs rapidly in the first 10 hours, with the oxidation rate slowing down significantly after 24 hours. Therefore, the steel tubes were preoxidized for 24 hours at $600{ }^{\circ} \mathrm{C}$ prior to sample preparation.

\section{$\underline{\text { Sample Preparation }}$}

The required components constituting the model deposit were mechanically mixed with a $50 \%$ isopropanol solution, to prepare a uniform slurry. The use of slurries to prepare ash deposits is in accordance with EU guidelines. ${ }^{36-38}$ The slurry was molded into 8 cubical shaped deposits on the superheater steel tube using a Teflon mold, as shown in Figure 2. The superheater steel tube was placed inside the mold, and the mold was securely closed using clamps. During the molding process, hooks used for tensile strength measurements were inserted into the mold, for allowing 
the deposit to be debonded perpendicular to the steel tube. Subsequently, the deposit slurry was injected into the mold, and shaped into cubical pellets, with sides of $15 \mathrm{~mm}$ each, leading to a contact surface area of $223 \mathrm{~mm}^{2}$. Thereafter, the Teflon mold was opened, leaving the superheater steel tube with 8 deposits.

It should be noted that the deposit formation process in boilers is different from the samples prepared in this study. 6,22

\section{Deposit Sintering}

The superheater steel tube containing the deposits was placed around a double annular cooling probe in an oven, and the deposit hooks were connected to the corresponding strength measurement arms, as shown in Figure 3. Air flowed through the channels of the cooling probe, with the primary air flowing in through the innermost channel and flowing out through the outermost channel, while the secondary air flowed through the annular region of the cooling probe, as shown in Figure 4a.

The following nomenclature has been used for referring to the different measured temperatures in the experimental setup (see Figure 4a).

- Flue gas temperature: The gas temperature in the oven heating chamber (oven temperature).

- Cooling probe temperature: Temperature at the outer surface of the cooling probe (and the inner surface of the superheater steel tube), measured at the axial centerpoint of the superheater steel tube. The flow rate of the primary air was controlled electronically, such that the cooling probe temperature is maintained at a desired value. The cooling probe could be maintained at a temperature up to $200{ }^{\circ} \mathrm{C}$ lower than that of the flue gas (oven 
temperature). The cooling probe temperature in the experimental setup is analogous to the steam temperature in boilers.

- Steel surface temperature: Temperature at the outer surface of the superheater steel tube, measured at the centerpoint of the deposit-tube interface. Eight deposits correspond to eight steel surface temperatures. The steel surface temperatures were higher than the cooling probe temperatures, due to the presence of a vertical temperature gradient $\left(\Delta \mathrm{T}_{\mathrm{v}}\right)$ across the steel tube. Furthermore, the steel surface temperature varied along the length of the superheater steel tube, due to the presence of a horizontal temperature gradient $\left(\Delta \mathrm{T}_{\mathrm{h}}\right)$.

The secondary air allowed additional cooling and reduced $\Delta \mathrm{T}_{\mathrm{h}}$. The flow rate of the secondary air was controlled manually using a rotameter, and was optimized to minimize $\Delta \mathrm{T}_{\mathrm{h}}$. It was identified that a secondary air flow rate of $50 \mathrm{NL} / \mathrm{min}$, which was the maximum possible flow rate, resulted in minimum temperature gradients across the steel tube, advocating the use of $50 \mathrm{NL} / \mathrm{min}$ of secondary air throughout all experiments.

The steel surface temperatures were measured by mounting 6 thermocouples on the outer surface of the superheater steel tube. The temperature gradients along the steel tube at a flue gas temperature of $650{ }^{\circ} \mathrm{C}$, and cooling probe temperatures of $450-650^{\circ} \mathrm{C}$, are shown in Figure $4 \mathrm{~b}$. It was observed that a horizontal temperature gradient of up to $64{ }^{\circ} \mathrm{C}$ existed along the steel surface $\left(\Delta \mathrm{T}_{\mathrm{h}}=0-64^{\circ} \mathrm{C}\right)$. It should be noted that the air supply to the cooling probe was shut off for the measurement corresponding to a cooling probe temperature of $650{ }^{\circ} \mathrm{C}$, resulting in isothermal conditions. Furthermore, the mean steel surface temperature was up to $88^{\circ} \mathrm{C}$ higher than the cooling probe temperature $\left(\Delta \mathrm{T}_{\mathrm{v}}=0-88^{\circ} \mathrm{C}\right)$. Both $\Delta \mathrm{T}_{\mathrm{h}}$ and $\Delta \mathrm{T}_{\mathrm{v}}$ decreased with increasing cooling probe temperature. Previous studies in full-scale boilers have identified that the steel surface temperature is typically around $20-50{ }^{\circ} \mathrm{C}$ higher than the steam temperature. ${ }^{22,39}$ 
It should be noted that the measurements to quantify the steel surface temperatures were performed in the absence of the deposits. The presence of the deposits might result in slight differences. Furthermore, the steel surface temperature was measured at 6 locations, whereas the superheater steel tube contained 8 deposits. The steel surface temperatures at the center of the deposits were interpolated linearly, wherever required, using the measured data.

After placing the superheater steel tube with the deposits around the cooling probe, the oven was heated to the required temperature at a uniform heating rate of $10{ }^{\circ} \mathrm{C} / \mathrm{min}$. Subsequently, the deposits were allowed to sinter for 2 hours. A purge air flow of $25 \mathrm{NL} / \mathrm{min}$, acting as the flue gas, was injected into the oven, in order to protect the heating elements from corrosion. Baseline experiments were performed with a flue gas temperature of $650{ }^{\circ} \mathrm{C}$, and a cooling probe temperature of $500{ }^{\circ} \mathrm{C}$, using a model deposit containing $\mathrm{KCl}$ and $\mathrm{K}_{2} \mathrm{SO}_{4}(50 \mathrm{wt} \%)$. Typical steam temperatures in biomass boilers range from $440-580{ }^{\circ} \mathrm{C}$, while typical flue gas temperatures in the superheater/tube bank region range from $580-1300^{\circ} \mathrm{C} .4,26,39,40$

\section{Measurement of Tensile Adhesion Strength}

After sintering, tensile adhesion strength measurements were performed using a movable actuator and load cell system mounted on the frame of the oven. For each measurement, the actuator was connected to the required strength measurement arm, pulling it slowly at a speed of $2.5 \mathrm{~mm} / \mathrm{s}$ to debond the deposit, while the corresponding force was measured using the load cell. The tensile adhesion strength was calculated by dividing the measured force by the contact area between the deposit and steel tube.

The strength measurement arms were directed through an air-cooled plate heat exchanger, installed in the outer shell of the oven, for protecting the heat-sensitive actuator and the load cell.

\section{$\underline{\text { Statistical data analysis using Welch's t-test }}$}


The two-tail Welch's t-test ${ }^{41}$ for unpaired data with unequal variances was performed on the experimental data, to analyze the statistical difference between two data sets. The test compared the two data sets, calculating the t-value $(T)$ as shown below,

$$
T=\frac{\mu_{1}-\mu_{2}}{\sqrt{\frac{\sigma_{1}^{2}}{N_{1}}+\frac{\sigma_{2}^{2}}{N_{2}}}}
$$

where $\mu$ and $\sigma$ are the mean and standard deviation of the data sets, and $\mathrm{N}$ represents the sample size. Subsequently, the p-value $(p)$ was calculated, as shown below,

$$
p=P\left(|T| \leq t_{1-\alpha / 2, v}\right)
$$

$t_{1-\alpha / 2, v}$ is the critical value of the $t$ distribution, where $v$ represents the degrees of freedom and $\alpha$ is the significance level. A typical value of 0.05 was chosen for the significance level, corresponding to a confidence level of $95 \%$, indicating that the data sets in consideration are significantly different if $p \leq 0.05$. Previous studies ${ }^{10,18}$ have indicated that the adhesion strength data for boiler deposits typically follow a log-normal distribution. Since the Welch's t-test requires that the data follow a normal distribution, the t-test was performed using the logarithmic values of the measured adhesion strength.

\section{Results and Discussion}

\section{$\underline{\text { Effect of Steel Surface Temperature }}$}

Figure 5 shows the effect of the steel surface temperature on the tensile adhesion strength of the investigated model deposit, containing $\mathrm{KCl}$ and $\mathrm{K}_{2} \mathrm{SO}_{4}(50 \mathrm{wt} \%$ ), which was sintered for 2 hours with a flue gas temperature of $650{ }^{\circ} \mathrm{C}$. The cooling probe temperature was varied from $450{ }^{\circ} \mathrm{C}$ to $650{ }^{\circ} \mathrm{C}$, resulting in the corresponding steel surface temperatures varying from $501{ }^{\circ} \mathrm{C}$ to $650{ }^{\circ} \mathrm{C}$. The experiments revealed that the tensile adhesion strength of the model deposits was low $(<12$ 
$\mathrm{kPa}$ ) at steel surface temperatures below $600{ }^{\circ} \mathrm{C}$ at the investigated conditions. Several deposits did not adhere to the steel tube, resulting in zero adhesion strength. However, the adhesion strength increased sharply at a steel surface temperature of $650{ }^{\circ} \mathrm{C}$, with a mean tensile adhesion strength of $31.79 \mathrm{kPa}$.

The two-tail Welch's t-test ${ }^{41}$ for unpaired data with unequal variances was performed on the experimental data, as shown in Table 3 . The results revealed that statistically significant difference did not exist between cooling probe temperatures of $450-500{ }^{\circ} \mathrm{C}$, and $500-600{ }^{\circ} \mathrm{C}$. However, adhesion strength data at a cooling probe temperature of $650^{\circ} \mathrm{C}$ was significantly different from adhesion strength data at $600{ }^{\circ} \mathrm{C}$, as well as $450{ }^{\circ} \mathrm{C}$, with p-values of 0.0425 and 0.0019 respectively. The results from the t-test substantiate the sharp increase in adhesion strength at 650 ${ }^{\circ} \mathrm{C}$.

Previous investigations have shown that corrosion leads to the formation of a partially molten layer at the deposit-tube interface, resulting in a sharp increase in adhesion strength. ${ }^{18}$ Corrosion occurs at the deposit-tube interface, resulting in the formation of $\mathrm{Fe} / \mathrm{Cr}$ chlorides, oxides, chromates, etc., with increasing steel surface temperatures causing a higher degree of corrosion. ${ }^{18,36,42,43}$ Since most of the corrosion products form a complex eutectic system with the $\mathrm{KCl}-\mathrm{K}_{2} \mathrm{SO}_{4}$ model deposit, ${ }^{44,45}$ a partially molten layer was formed at the deposit-tube interface, even below the eutectic temperature of the $\mathrm{KCl}-\mathrm{K}_{2} \mathrm{SO}_{4}$ system $\left(690{ }^{\circ} \mathrm{C}\right)$. The partially molten layer increased the physical contact area between the deposit and the tube on a molecular scale, thereby increasing adsorption. Furthermore, the corrosion reactions occurring between the deposit and the steel tube may have increased surface adhesion. ${ }^{46}$ Visual observations of the deposit-tube interface after debonding indicated the presence of a thick corrosion layer at steel surface temperatures of $650{ }^{\circ} \mathrm{C}$. 
It should be noted that debonding always occurred at the deposit-tube interface for the aforementioned experiments. The results concur with previous lab-scale investigations, ${ }^{18}$ where a sharp increase in adhesion strength was observed near the melting temperature/ash deformation temperature of the ash deposit, as well as full-scale deposit probe investigations, ${ }^{9}$ where deposits formed on a steel tube at higher steel surface temperatures required larger sootblowing peak impact pressures to be removed. Furthermore, the mean tensile adhesion strength of the $\mathrm{KCl}-\mathrm{K}_{2} \mathrm{SO}_{4}(50$ wt \%) deposits measured in this study at $650^{\circ} \mathrm{C}$ and isothermal conditions $(31.79 \mathrm{kPa})$, is similar in magnitude to the mean shear adhesion strength of $\mathrm{KCl}-\mathrm{K}_{2} \mathrm{SO}_{4}(50 \mathrm{wt} \%)$ deposits at $650{ }^{\circ} \mathrm{C}$ $(30.82 \mathrm{kPa})$, measured in a previous study. ${ }^{18}$

A high degree of scatter was observed in the present experimental data. Previous lab-scale, ${ }^{10,18}$ as well full-scale ${ }^{9}$ studies have also indicated that adhesion strength data for boiler deposits display a high degree of scatter, typically following a log-normal distribution.

\section{Effect of Flue Gas Temperature}

In order to investigate the effect of flue gas temperature on the tensile adhesion strength of ash deposits, experiments were carried out with model deposits containing $\mathrm{KCl}$ and $\mathrm{K}_{2} \mathrm{SO}_{4}$ (50 wt \%). The deposits were sintered for 2 hours, with the cooling probe temperature maintained at $500{ }^{\circ} \mathrm{C}$, while the flue gas temperature was varied from $500-700{ }^{\circ} \mathrm{C}$.

As seen in Figure 6, it was observed that the tensile adhesion strength of the model deposits did not change significantly with flue gas temperatures of $500-650{ }^{\circ} \mathrm{C}$, at the investigated conditions. The mean steel surface temperature varied from $500-558{ }^{\circ} \mathrm{C}$, when the flue gas temperature was varied from $500-650{ }^{\circ} \mathrm{C}$. However, when the flue gas temperature was increased to $700{ }^{\circ} \mathrm{C}$, a sharp increase in tensile adhesion strength was observed. At a flue gas temperature of $700{ }^{\circ} \mathrm{C}$, and a cooling probe temperature of $500{ }^{\circ} \mathrm{C}$, the steel surface temperature was $576{ }^{\circ} \mathrm{C}$. Statistical 
analysis of the obtained experimental data using Welch's t-test (see Table 4) confirmed that the data set corresponding to a flue temperature of $700^{\circ} \mathrm{C}$ was significantly different from the data set corresponding to $650{ }^{\circ} \mathrm{C}$, whereas no statistically significant difference could be observed from $500-650{ }^{\circ} \mathrm{C}$.

In order to understand the increase in tensile adhesion strength at a flue gas temperature of 700 ${ }^{\circ} \mathrm{C}$, the corresponding deposit was analyzed using Scanning Electron Microscopy and Energydispersive X-ray spectroscopy. The debonded deposit was cast in epoxy and polished, without any exposure to water, thereby preventing any dissolution, recrystallization, and removal of salts. The images revealed the presence of a thick molten layer at the deposit-tube interface, as shown in Figure $7 \mathrm{~b} . \mathrm{K}_{2} \mathrm{SO}_{4}$ particles were suspended in the $\mathrm{KCl}-\mathrm{K}_{2} \mathrm{SO}_{4}$ melt, where the composition of $\mathrm{KCl}$ in the melt was $8 \mathrm{wt} \%$. However, $\mathrm{KCl}$ particles could be identified in the outer layer of the deposit (see Figure 7a).

The high molten content at the deposit-tube interface may be attributed to several factors. At a flue gas temperature of $700{ }^{\circ} \mathrm{C}$, the outer layer of the $\mathrm{KCl}-\mathrm{K}_{2} \mathrm{SO}_{4}$ model deposit became partially molten, since $\mathrm{KCl}$ and $\mathrm{K}_{2} \mathrm{SO}_{4}$ form a eutectic system with a eutectic temperature of $690{ }^{\circ} \mathrm{C}$ (see Table 1). As a result, the molten outer layer probably trickled down through the pores of the deposit, due to capillary and gravitational forces, solidifying at lower temperatures near the deposit-tube interface. This phenomenon is observed in full-scale boilers in the form of liquid state sintering, ${ }^{5,47,48}$ resulting in the formation of hard and strongly adherent deposits, and has been observed in previous experimental investigations. ${ }^{19,49,50}$

Sintering increases the bulk density and thermal conductivity of the deposits, ${ }^{51}$ thereby increasing the temperature of the deposit over time, and further increasing the molten content at the deposit-tube interface. Furthermore, significant gas phase migration may have occurred within 
the deposit, where species on the outer layer of the deposit vaporized, diffused through the pores of the deposit, and eventually condensed near the deposit-tube interface. ${ }^{50}$ Therefore, the high molten/condensed content at the deposit-tube interface increased the surface wetting and therefore, increased the tensile adhesion strength.

It should be noted that the dissolution of $\mathrm{KCl}$ and $\mathrm{K}_{2} \mathrm{SO}_{4}$ in the $50 \%$ isopropanol solution during sample preparation may have increased the molten content at the deposit-tube interface. Furthermore, corrosion occurring at the deposit-tube interface may have contributed towards the formation of the molten layer. ${ }^{18}$ However, with a steel surface temperature of $576{ }^{\circ} \mathrm{C}$, the corrosion layer is not expected to cause a significant increase in the tensile adhesion strength, as suggested by the results described in Figure 5.

Increasing the flue gas temperature to $750{ }^{\circ} \mathrm{C}$ led to a high degree of molten content, which severely reduced the deposit thickness, such that the adhesion strength could not be measured.

The results suggest that a temperature gradient across the deposit may induce migration of molten/vapor species from the outer layer of the deposit to the deposit-tube interface, causing liquid state sintering, and possibly leading to an increase in deposit adhesion strength. However, further investigation, spanning over a larger range of flue gas temperatures and time is required to completely understand the effect of sintering on adhesion strength.

\section{$\underline{\text { Effect of Deposit Composition }}$}

In order to understand the effect of different components present in ash deposits, the composition of the model deposits was varied by adding $\mathrm{CaO}, \mathrm{CaSO}_{4}$ and $\mathrm{K}_{2} \mathrm{Si}_{4} \mathrm{O}_{9}$ to the $\mathrm{KCl}-\mathrm{K}_{2} \mathrm{SO}_{4}$ model deposit. Furthermore, experiments were conducted with the straw fly ash obtained from the Avedøreværket grate-fired boiler (see Table 2 for fly ash properties and Figure 1 for particle size distribution). 
Figure 8 shows the effect of deposit composition on the tensile adhesion strength. The addition of $\mathrm{CaO}$ to the model deposit containing $\mathrm{KCl}$ and $\mathrm{K}_{2} \mathrm{SO}_{4}$ considerably decreased the adhesion strength at the investigated conditions, with several deposits not adhering to the steel tubes. Comparing the adhesion strength data of the model deposit containing $\mathrm{KCl}$ and $\mathrm{K}_{2} \mathrm{SO}_{4}(50 \mathrm{wt} \%)$ with the model deposit containing $\mathrm{KCl}, \mathrm{K}_{2} \mathrm{SO}_{4}$ and $\mathrm{CaO}$ (33 wt \%) using Welsh's t-test, the obtained p-value was 0.0011 (see Table 5), implying that the difference in the data sets is statistically significant.

Calcium is widely present in deposits formed in coal and wood-fired boilers, primarily as oxides and sulfates. ${ }^{22,52}$ Since $\mathrm{CaO}$ does not form a eutectic melt with the $\mathrm{KCl}-\mathrm{K}_{2} \mathrm{SO}_{4}$ system, the addition of $\mathrm{CaO}$ reduced the melt fraction, thereby decreasing adhesion strength. ${ }^{18}$

However, as shown in Figure 8, the addition of $\mathrm{CaSO}_{4}$ significantly increased the adhesion strength of the model deposit containing $\mathrm{KCl}$ and $\mathrm{K}_{2} \mathrm{SO}_{4}$. The increase in adhesion strength, which was determined to be statistically significant (see Table 5), can be attributed to the fact that $\mathrm{KCl}-$ $\mathrm{K}_{2} \mathrm{SO}_{4}-\mathrm{CaSO}_{4}$ form a eutectic system, with a eutectic temperature of $644{ }^{\circ} \mathrm{C}$ (see Table 1 ). As a result, a molten layer at the outer surface of the deposit was formed, which probably trickled down through the deposit pores to induce liquid state sintering and therefore, increased the tensile adhesion strength of the deposits. Furthermore, corrosion occurring at the deposit-tube interface may have resulted in an increased melt fraction at the interface, since the corrosion products form a complex eutectic system with $\mathrm{KCl}, \mathrm{K}_{2} \mathrm{SO}_{4}$ and $\mathrm{CaSO}_{4}{ }^{25}$

$\mathrm{CaO}$ in boilers may react with $\mathrm{SO}_{2}$ or $\mathrm{SO}_{3}$ in the flue gas to undergo sulfation, forming $\mathrm{CaSO}_{4}{ }^{53-}$ ${ }^{55}$ Sulfation may occur in the gas phase prior to deposition, or in the solid phase after deposition on boiler surfaces. ${ }^{18}$ Furthermore, iron oxide in the steel may catalytically convert $\mathrm{SO}_{2}$ to $\mathrm{SO}_{3},{ }^{45,56}$ 
thereby catalyzing the overall sulfation reaction and increasing the concentration of $\mathrm{CaSO}_{4}$ near the steel surface.

Replacing $\mathrm{CaO}$ with $\mathrm{CaSO}_{4}$ in the model deposit resulted in an increase in deposit adhesion strength, indicating that sulfation of $\mathrm{Ca}$ in boilers may result in the formation of strongly adherent deposits. Previous investigations have also indicated that sulfation of ash deposits may increase their adhesion strength. ${ }^{18}$ However, further investigation is required to completely understand the effect of sulfation on ash deposits.

The presence of silicates has been identified in slagging deposits, and in sintered biomass ash deposits. ${ }^{5,22,57}$ The addition of $\mathrm{K}_{2} \mathrm{Si}_{4} \mathrm{O}_{9}$ to the model deposit containing $\mathrm{KCl}$ and $\mathrm{K}_{2} \mathrm{SO}_{4}$ increased its adhesion strength, as shown in Figure 8. The increase in tensile adhesion strength was statistically significant (see Table 5). Differential Scanning Calorimetry (DSC) analysis of $\mathrm{K}_{2} \mathrm{Si}_{4} \mathrm{O}_{9}$ in a previous investigation ${ }^{18}$ has revealed the formation of a glass phase at $650{ }^{\circ} \mathrm{C}$. The formation of glass phase probably caused deposit sintering and increased the contact area between the deposit and the tube, thereby increasing the tensile adhesion strength of the deposits.

The tensile adhesion strength of deposits prepared from straw fly ash was similar in magnitude to model deposits containing $\mathrm{KCl}$ and $\mathrm{K}_{2} \mathrm{SO}_{4}(50 \mathrm{wt} \%)$. Statistical analysis using Welch's t-test indicated that significant statistical difference between the corresponding two data sets did not exist (see Table 5). This can be attributed to the composition of the straw fly ash, which is dominated by $\mathrm{KCl}$ and $\mathrm{K}_{2} \mathrm{SO}_{4}$ (approximately $50 \mathrm{wt} \%$ each). The results further suggest that the difference in particle size distribution of the straw fly ash and the model deposit did not significantly influence the tensile adhesion strength.

The tensile adhesion strength of biomass ash deposits investigated in this study is similar in magnitude to the shear adhesion strength of biomass ash deposits, as seen from a comparison with 
previous lab-scale investigations ${ }^{18}(1-350 \mathrm{kPa})$ and full-scale investigations $(20-250 \mathrm{kPa}),{ }^{9}$ as well as coal ash deposits from lab-scale investigations $(35-350 \mathrm{kPa}) .{ }^{11-13}$ However, the deposits from kraft recovery boilers possess a higher adhesion strength, as seen from lab-scale investigations $(1000-16000 \mathrm{kPa}) .{ }^{10}$

The present results allow better understanding of deposit shedding in boilers, and recognize the influence of melt fraction at the deposit-tube interface, corrosion and sintering on deposit adhesion strength in boilers.

\section{Conclusions}

The tensile adhesion strength of model deposits containing $\mathrm{KCl}, \mathrm{K}_{2} \mathrm{SO}_{4}, \mathrm{CaO}, \mathrm{CaSO}_{4}, \mathrm{~K}_{2} \mathrm{Si}_{4} \mathrm{O}_{9}$, as well as straw fly ash obtained from a grate-fired boiler, was investigated in this study. Artificial ash deposits were prepared on superheater steel tubes, and sintered in an oven under the influence of a temperature gradient across the deposits. The effects of flue gas temperature, steel surface temperature and deposit composition were investigated.

The results revealed that the tensile adhesion strength of the model deposits containing $\mathrm{KCl}$ and $\mathrm{K}_{2} \mathrm{SO}_{4}(50$ wt $\%)$ was low $(<12 \mathrm{kPa})$ at steel surface temperatures below $600{ }^{\circ} \mathrm{C}$, with several deposits not adhering to the steel tube. However, the tensile adhesion strength increased sharply at a steel surface temperature of $650{ }^{\circ} \mathrm{C}$ at the investigated conditions, with a mean value of 31.79 $\mathrm{kPa}$. Corrosion products created at the deposit-tube interface formed a eutectic system with the deposit constituents at $650{ }^{\circ} \mathrm{C}$, thereby forming a partially molten layer at the deposit-tube interface, and increasing the adhesion strength.

Furthermore, the results showed that varying the flue gas temperature from $500-650^{\circ} \mathrm{C}$ did not have a significant effect on the adhesion strength of the model deposits. However, at a flue gas 
temperature of $700{ }^{\circ} \mathrm{C}$, a sharp increase in the tensile adhesion strength was observed. The temperature gradient across the deposits, at a flue gas temperature of $700{ }^{\circ} \mathrm{C}$, induced migration of molten/vapor species from the outer layer of the deposit to the deposit-tube interface, causing liquid state sintering, and thereby increasing the tensile adhesion strength.

Variation of the chemistry of the model deposits revealed that the melt fraction of the ash deposit is an important parameter for determining deposit adhesion strength. Addition of compounds which increased the melt fraction of the deposit increased the tensile adhesion strength, whereas addition of inert compounds with a high melting point, such as $\mathrm{CaO}$, decreased the tensile adhesion strength. Furthermore, the tensile adhesion strength of the deposits prepared using straw fly ash was similar in magnitude to model deposits containing $\mathrm{KCl}$ and $\mathrm{K}_{2} \mathrm{SO}_{4}$. 


\section{Acknowledgements}

This work is part of the project, 'Flexible use of Biomass on PF fired power plants', funded by Energinet, through the ForskEL program, Ørsted Bioenergy \& Thermal Power A/S, and DTU.

\section{References}

(1) UNFCCC. Adoption of the Paris Agreement, Report no. FCCC/CP/2015/L.9/Rev.1; 2015.

(2) Renewables 2017: Global Status Report; REN21 Secretariat: Paris, 2017, ISBN: 978-39818107-6-9.

(3) The Danish Government. Our Future Energy; 2011, ISBN: 978-87-7844-915-3.

(4) Wu, H.; Bashir, M. S.; Jensen, P. A.; Sander, B.; Glarborg, P. Fuel 2013, 113, 632-643.

(5) Frandsen, F. Ash formation, deposition and corrosion when utilizing straw for heat and power production; Technical University of Denmark, Department of Chemical and Biochemical Engineering, 2010, ISBN: 978-87-92481-40-5.

(6) Zhou, H.; Jensen, P. A.; Frandsen, F. J. Fuel 2007, 86 (10-11), 1519-1533.

(7) Hansen, S. B. Model for Deposition Build-up in Biomass Boilers. Ph.D. Thesis, Technical University of Denmark, 2015.

(8) Zbogar, A.; Frandsen, F.; Jensen, P. A.; Glarborg, P. Prog. Energy Combust. Sci. 2009, 35 (1), 31-56.

(9) Bashir, M. S.; Jensen, P. A.; Frandsen, F.; Wedel, S.; Dam-Johansen, K.; Wadenbäck, J. Energy Fuels 2012, 26 (8), 5241-5255. 
(10) Kaliazine, A.; Cormack, D. E.; Ebrahimi-Sabet, A.; Tran, H. J. Pulp Pap. Sci. 1999, 25 (12), 418-424.

(11) Moza, A. K.; Austin, L. G. Fuel 1981, 60 (11), 1057-1064.

(12) Moza, A. K.; Shoji, K.; Austin, L. G. J. Inst. Energy 1980, 53 (414), 17-19.

(13) Raask, E. VGB Kraftwerkstechnik 1973, 53 (4), 248-254.

(14) Attig, R. C.; Barnhart, D. H. In The Mechanism of Corrosion by Fuel Impurities; Johnson, H. R., Littler, D. J., Eds.; Butterworth: London: Butterworth, London, 1963; p 173.

(15) Conn, R. E.; Jones, M. L. In Third engineering foundation conference on slagging and fouling due to impurities in combustion gases; Barrett, R. E., Ed.; Copper Mountain, CO, 1984; pp 207-228.

(16) Cumming, I. W.; Joyce, W. I.; Kyle, J. H. J. Inst. Energy 1985, 58, 169-175.

(17) Yilu, S. In Third engineering foundation conference on slagging and fouling due to impurities in combustion gases; Barrett, R. E., Ed.; Copper, 1984; pp 557-592.

(18) Laxminarayan, Y.; Jensen, P. A.; Wu, H.; Frandsen, F. J.; Sander, B.; Glarborg, P. Energy Fuels 2017, 31 (8), 8733-8741.

(19) Lindberg, D.; Niemi, J.; Engblom, M.; Yrjas, P.; Laurén, T.; Hupa, M. Fuel Process. Technol. 2016, 141, 285-298.

(20) Kawahara, Y. Mater. Corros. 2006, 57 (1), 60-72.

(21) Brossard, J. M.; Diop, I.; Chaucherie, X.; Nicol, F.; Rapin, C.; Vilasi, M. Mater. Corros. 
2011, 62 (6), 543-548.

(22) Jensen, P. A.; Frandsen, F. J.; Hansen, J.; Dam-Johansen, K.; Henriksen, N.; Hörlyck, S. Energy Fuels 2004, 18 (2), 378-384.

(23) Chipman, J. J. Am. Chem. Soc. 1926, 48 (10), 2577-2589.

(24) Pagels, J.; Strand, M.; Rissler, J.; Szpila, A.; Gudmundsson, A.; Bohgard, M.; Lillieblad, L.; Sanati, M.; Swietlicki, E. J. Aerosol Sci. 2003, 34 (8), 1043-1059.

(25) Janz, G. J.; Allen, C. B.; Downey Jr, J. R.; Tomkins, R. P. T. Physical properties data compilations relevant to energy storage. I. Molten salts: Eutectic Data; 1978.

(26) Bashir, M. S.; Jensen, P. A.; Frandsen, F.; Wedel, S.; Dam-Johansen, K.; Wadenbäck, J.; Pedersen, S. T. Fuel Process. Technol. 2012, 97, 93-106.

(27) European Committee for Standardization. Solid biofuels- Method for the determination of ash melting behaviour - Part 1: Characteristic temperatures method, CEN/TS 15370$1: 2006 ; 2006$.

(28) Hamzah, M. Z.; Yeo, W. H.; Fry, A. T.; Inayat-Hussain, J. I.; Ramesh, S.; Purbolaksono, J. Eng. Fail. Anal. 2013, 35, 380-386.

(29) Schmidt, D.; Schütze, M. Mater. Sci. Forum 2011, 696, 330-335.

(30) Yukitoshi, T.; Yoshikawa, K.; Daikoku, T.; Masuyama, F. J. Mater. Energy Syst. 1982, 4 (2), 99-109.

(31) Zahs, A.; Spiegel, M.; Grabke, H. J. Corros. Sci. 2000, 42 (6), 1093-1122. 
(32) Okoro, S. C.; Kiamehr, S.; Montgomery, M.; Frandsen, F. J.; Pantleon, K. Mater. Corros. 2017, $68(5), 499-514$.

(33) Israelsson, N.; Engkvist, J.; Hellström, K.; Halvarsson, M.; Svensson, J. E.; Johansson, L. G. Oxid. Met. 2014, 83 (1-2), 29-53.

(34) Sabau, A. S.; Wright, I. G.; Shingledecker, J. P. Mater. Corros. 2012, 63 (10), 896-908.

(35) Rizzi, M.; Guerrini, E.; Trasatti, S. P. Metall. Ital. 2012, No. 2, 29-35.

(36) Okoro, S. C.; Montgomery, M.; Frandsen, F. J.; Pantleon, K. Energy Fuels 2014, 28 (10), $6447-6458$.

(37) Coleman, K. E.; Simms, N. J.; Kilgallon, P. J.; Oakey, J. E. Mater. Sci. Forum 2008, 595598, 377-386.

(38) Grabke, H. J.; Meadowcroft, D. B. A working party report on guidelines for methods of testing and research in high temperature corrosion; European Federation of Corrosion: London, 1995, ISBN: 1907625828.

(39) Montgomery, M.; Karlsson, A.; Larsen, O. H. Mater. Corros. 2002, 53 (2), 121-131.

(40) Montgomery, M.; Jensen, S. A.; Borg, U.; Biede, O.; Vilhelmsen, T. Mater. Corros. 2011, $62(7), 593-605$.

(41) Welch, B. L. Biometrika 1947, 34 (1), 28-35.

(42) Sui, J.; Lehmusto, J.; Bergelin, M.; Hupa, M. Oxid. Met. 2014, 82 (5-6), 437-456.

(43) Spiegel, M. Mater. Corros. 1999, 50 (7), 373-393. 
(44) Viklund, P.; Hjörnhede, A.; Henderson, P.; Stålenheim, A.; Pettersson, R. Fuel Process. Technol. 2013, 105, 106-112.

(45) Nielsen, H. P.; Frandsen, F. J.; Dam-Johansen, K. Energy Fuels 1999, 13 (6), 1114-1121.

(46) Packham, D. E. In Handbook of Adhesion Technology; da Silva, L. F. M., Öchsner, A., Adams, R. D., Eds.; Springer Berlin Heidelberg: Berlin, Heidelberg, 2011; pp 9-38.

(47) Raask, E. Mineral impurities in coal combustion: behavior, problems, and remedial measures; Taylor \& Francis, 1985.

(48) Zhang', D.; Jackson, P. J.; Vuthaluru, H. B. In Impact of Mineral Impurities in Solid Fuel Combustion; Gupta, R., Wall, T., Baxter, L., Eds.; Kluwer Academic Publishers: New York, 1999; pp 45-64.

(49) German, R. M.; Suri, P.; Park, S. J. J. Mater. Sci. 2009, 44 (1), 1-39.

(50) Niemi, J.; Lindberg, D.; Engblom, M.; Hupa, M. Chem. Eng. Sci. 2017, 173, 196-207.

(51) Zbogar, A.; Frandsen, F. J.; Jensen, P. A.; Glarborg, P. Prog. Energy Combust. Sci. 2005, $31(5-6), 371-421$.

(52) Raask, E. Prog. Energy Combust. Sci. 1982, 8, 261-276.

(53) Anthony, E. J.; Granatstein, D. L. Prog. Energy Combust. Sci. 2001, 27 (2), 215-236.

(54) Borgwardt, R. H.; Bruce, K. R. AIChE J. 1986, 32 (2), 239-246.

(55) Marsh, D. W. Chem. Eng. Sci. 1985, 40 (3), 423-433.

(56) Jørgensen, T. L.; Livbjerg, H.; Glarborg, P. Chem. Eng. Sci. 2007, 62 (16), 4496-4499. 
(57) Hansen, L. A.; Nielsen, H. P.; Frandsen, F. J.; Dam-Johansen, K.; Hørlyck, S.; Karlsson, A. Fuel Process. Technol. 2000, 64 (1), 189-209. 


\section{FIGURES}

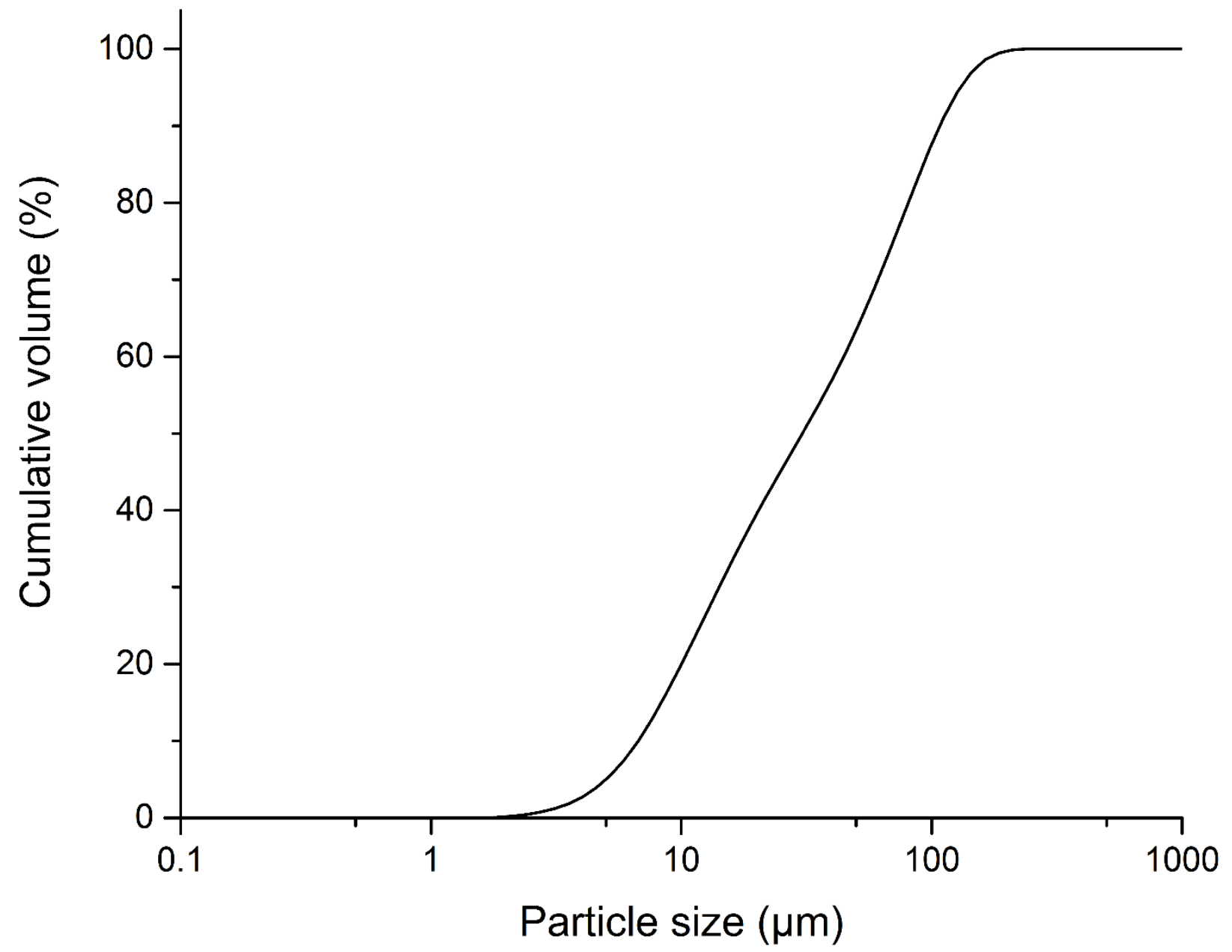

Figure 1. Particle size distribution of the investigated straw fly ash, obtained using a Malvern Mastersizer 3000. $\mathrm{D}_{10}=8.01 \mu \mathrm{m}, \mathrm{D}_{50}=51.7 \mu \mathrm{m}, \mathrm{D}_{90}=142 \mu \mathrm{m}$. 

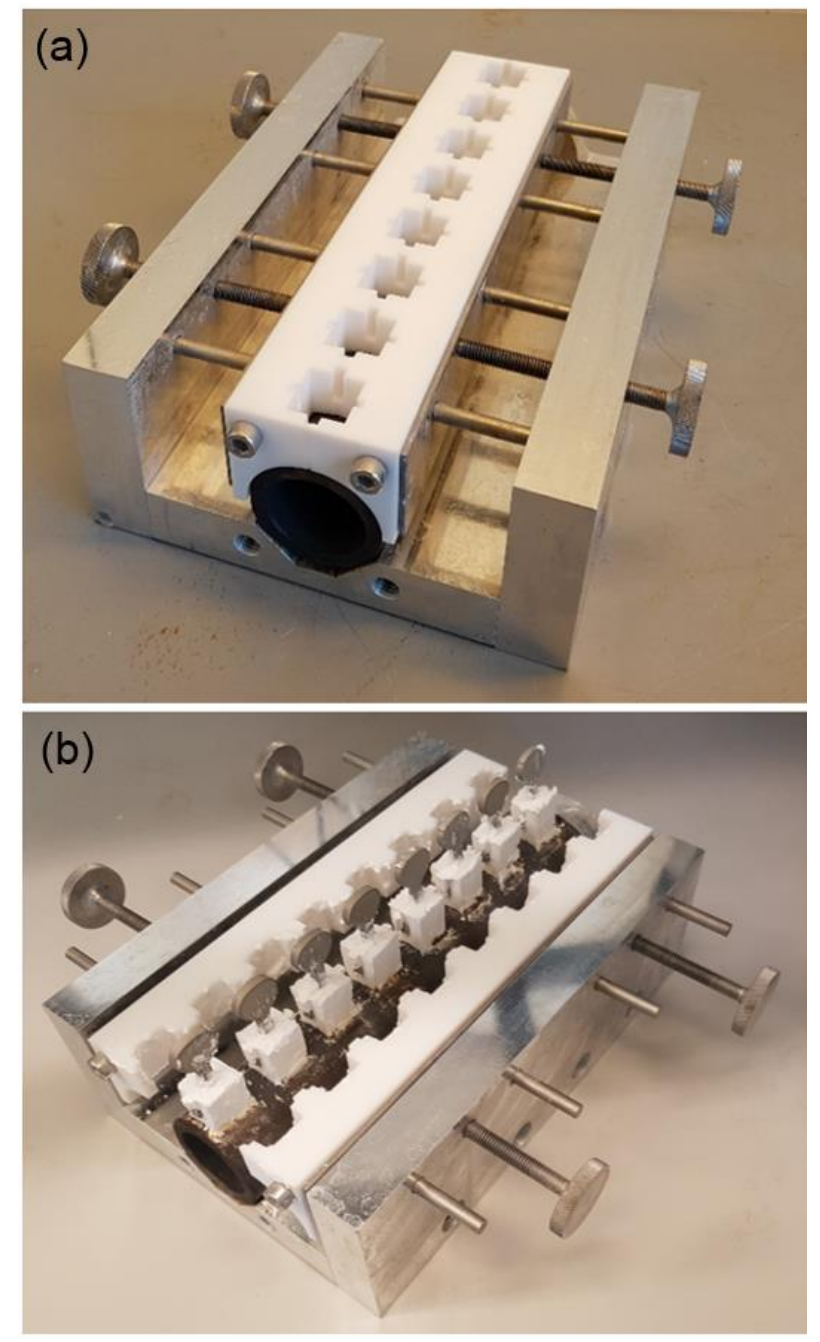

Figure 2. Teflon mold used for sample preparation. After the superheater steel tube was positioned (a), the hooks were inserted into the mold, followed by injection of the deposit slurry. Subsequently, the deposits and the superheater steel tube were removed, by opening the Teflon mold (b). 


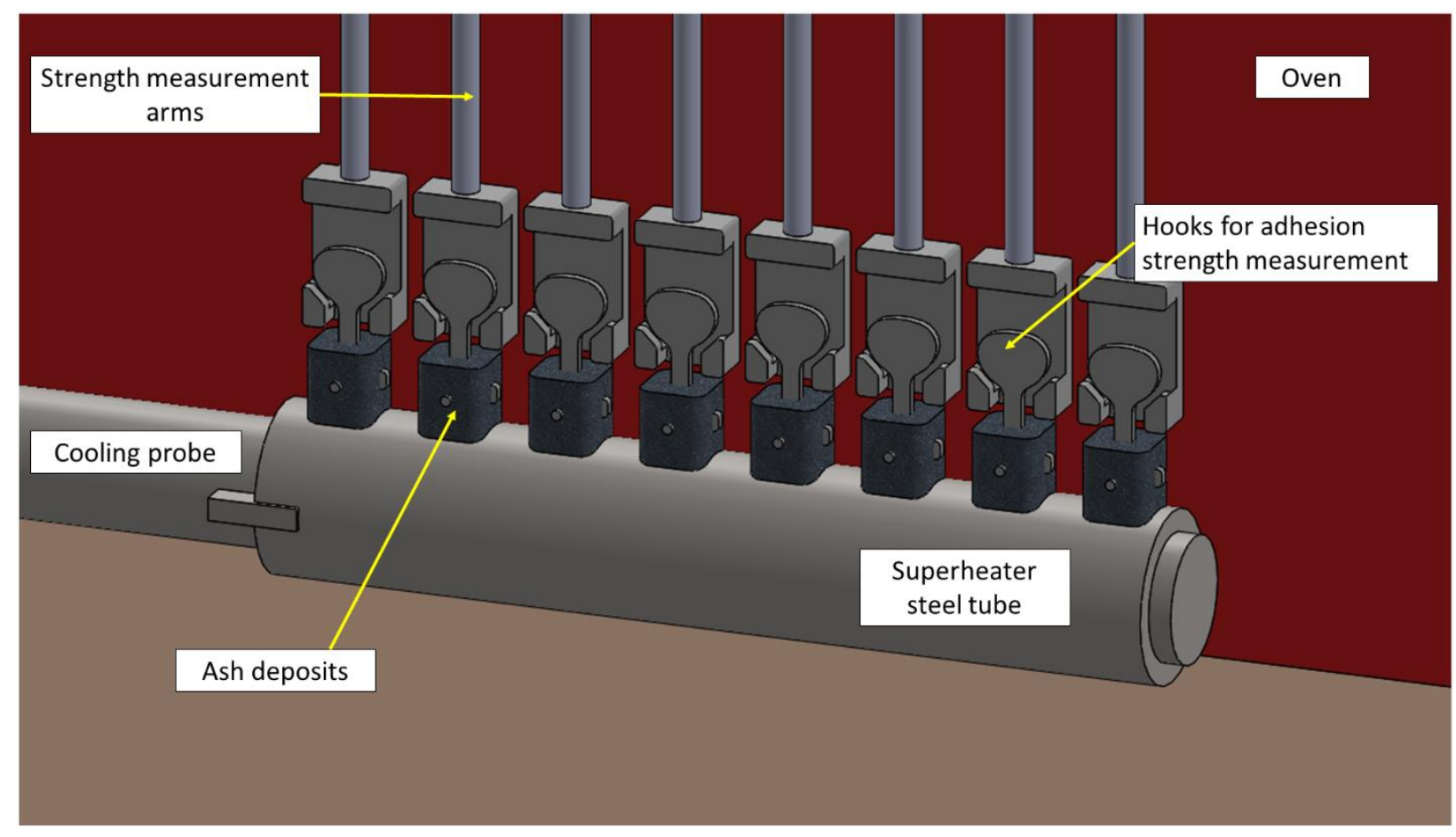

Figure 3. Experimental setup for adhesion strength measurements. The superheater steel tube with the deposits was placed around the air-cooled probe inside the oven, and the deposits were connected to the strength measurement arms. 


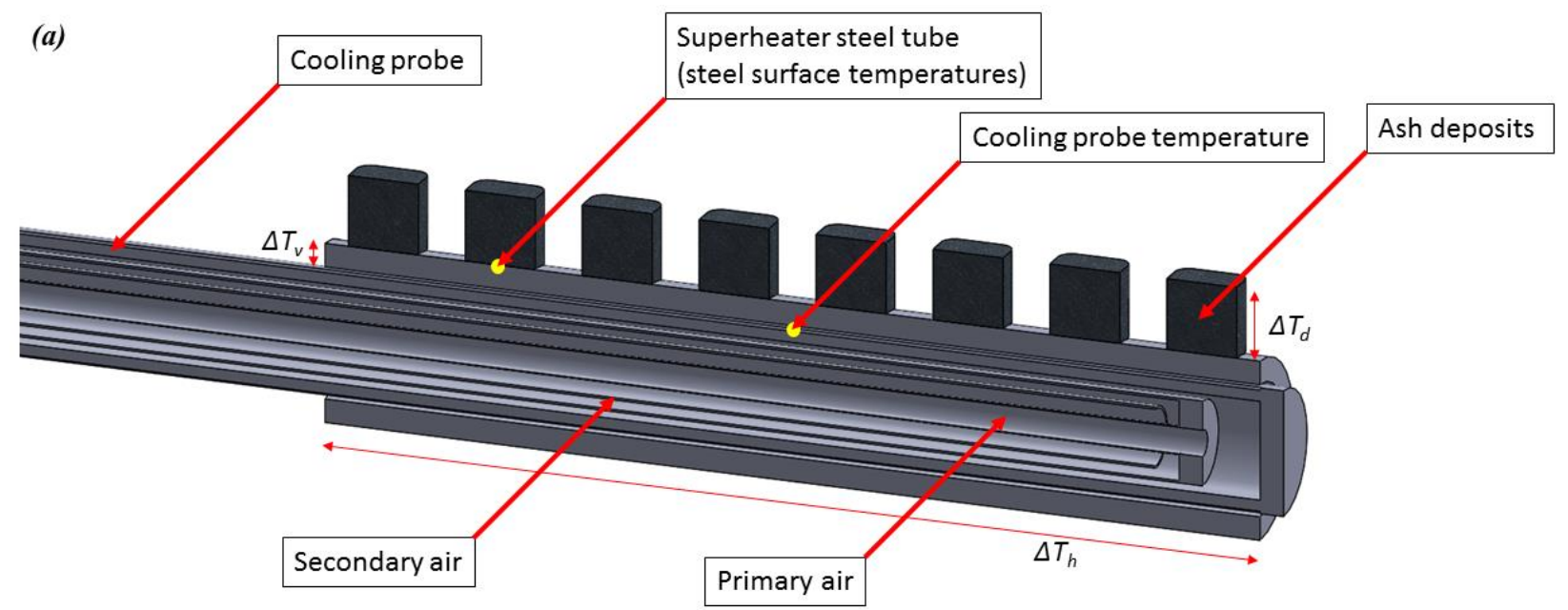

(b)

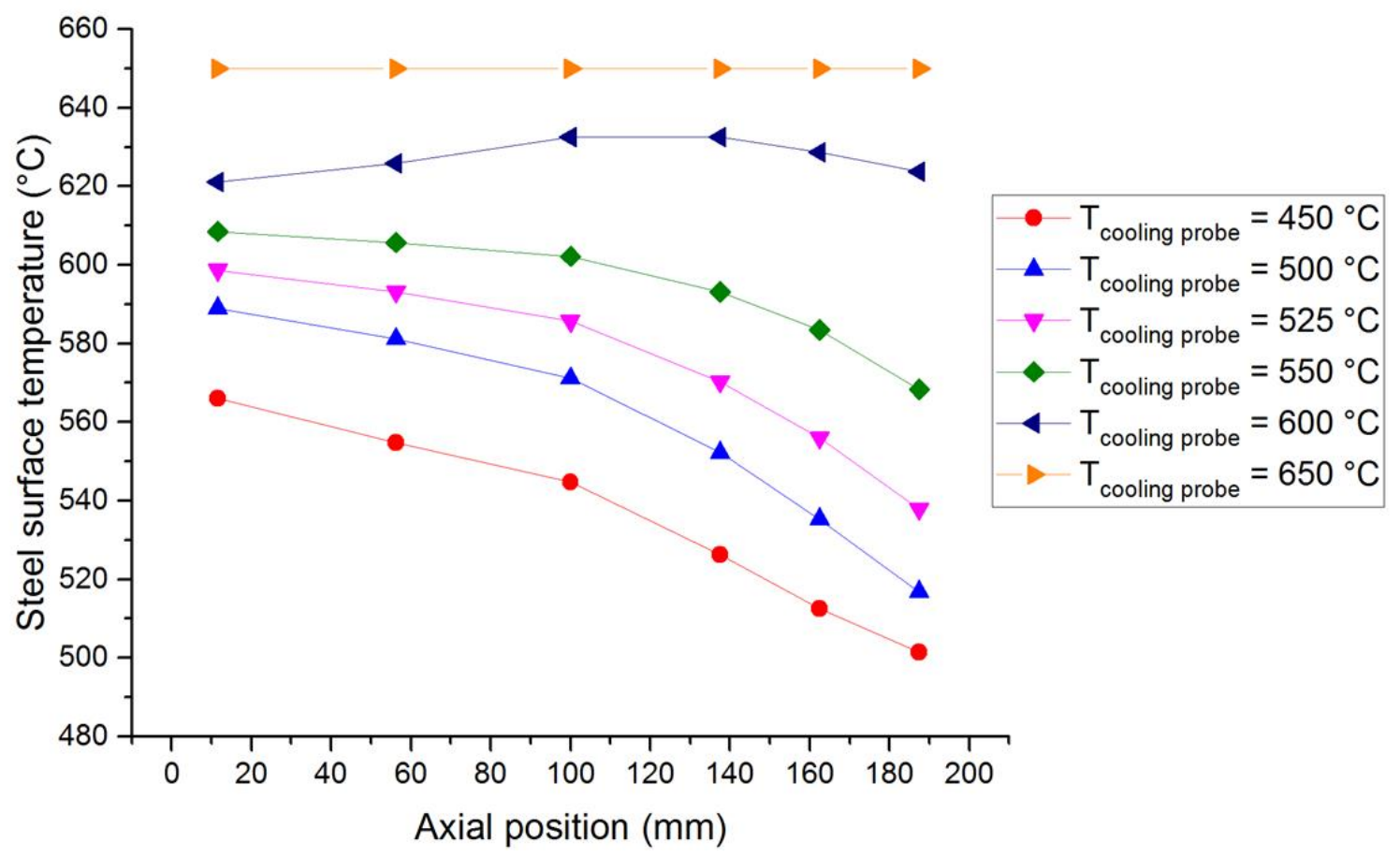

Figure 4. (a) Cross-sectional view of the mounted air-cooled probe. The cooling probe temperature was measured on the outer surface of the cooling probe (below the superheater steel tube) at the axial centerpoint of the superheater steel tube. Steel surface temperatures refer to the temperatures at the outer surface of the superheater steel tube. Horizontal and vertical temperature gradients exist along/across the superheater steel tube and the deposits. (b) Temperature gradients along the outer surface of the superheater steel tube, with a flue gas temperature of $650{ }^{\circ} \mathrm{C}$. Axial position measured from the left edge of the superheater steel tube. 


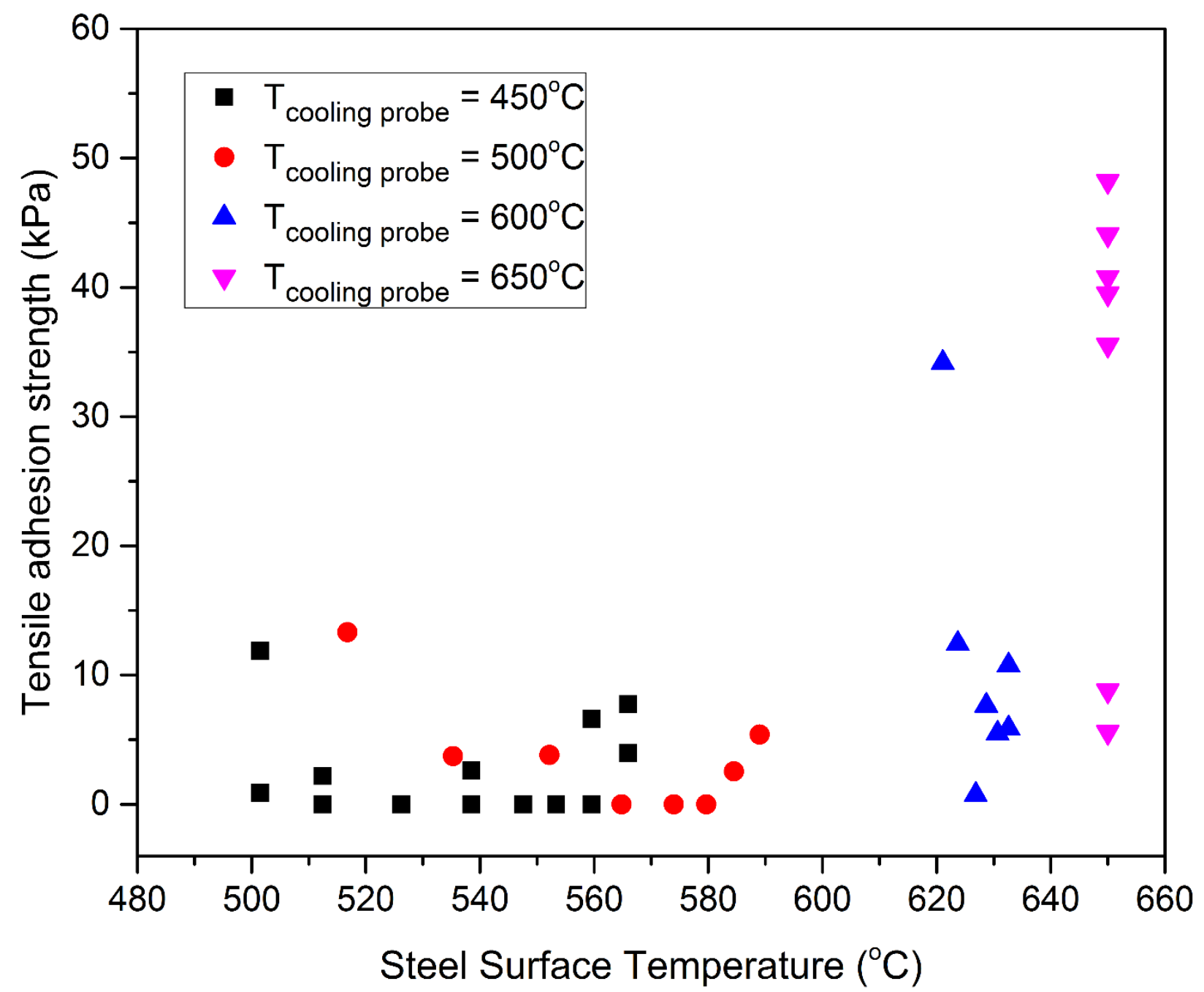

Figure 5. Effect of steel surface temperature on tensile adhesion strength. $\mathrm{KCl}-\mathrm{K}_{2} \mathrm{SO}_{4}(50 \mathrm{wt} \%)$ deposits, sintered with a flue gas temperature of $650{ }^{\circ} \mathrm{C}$ for $2 \mathrm{~h}$. Superheater steel (TP347HFG) preoxidized for $24 \mathrm{~h}$. 


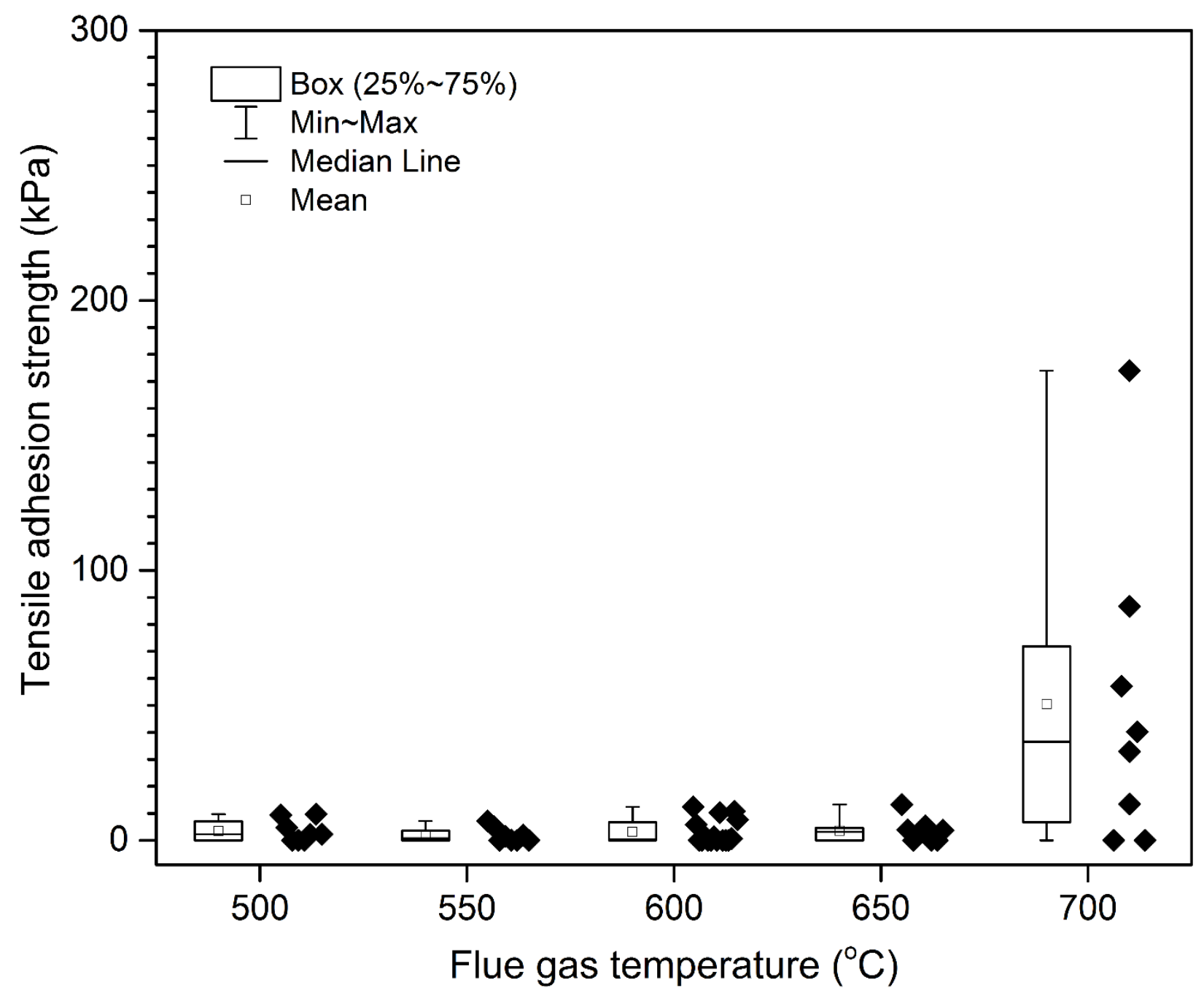

Figure 6. Effect of flue gas temperature on tensile adhesion strength. $\mathrm{KCl}-\mathrm{K}_{2} \mathrm{SO}_{4}(50$ wt \%) deposits, sintered with a cooling probe temperature of $500{ }^{\circ} \mathrm{C}$ for $2 \mathrm{~h}$. Mean steel surface temperatures varied from $500-576^{\circ} \mathrm{C}$. Superheater steel (TP347HFG) preoxidized for $24 \mathrm{~h}$. 

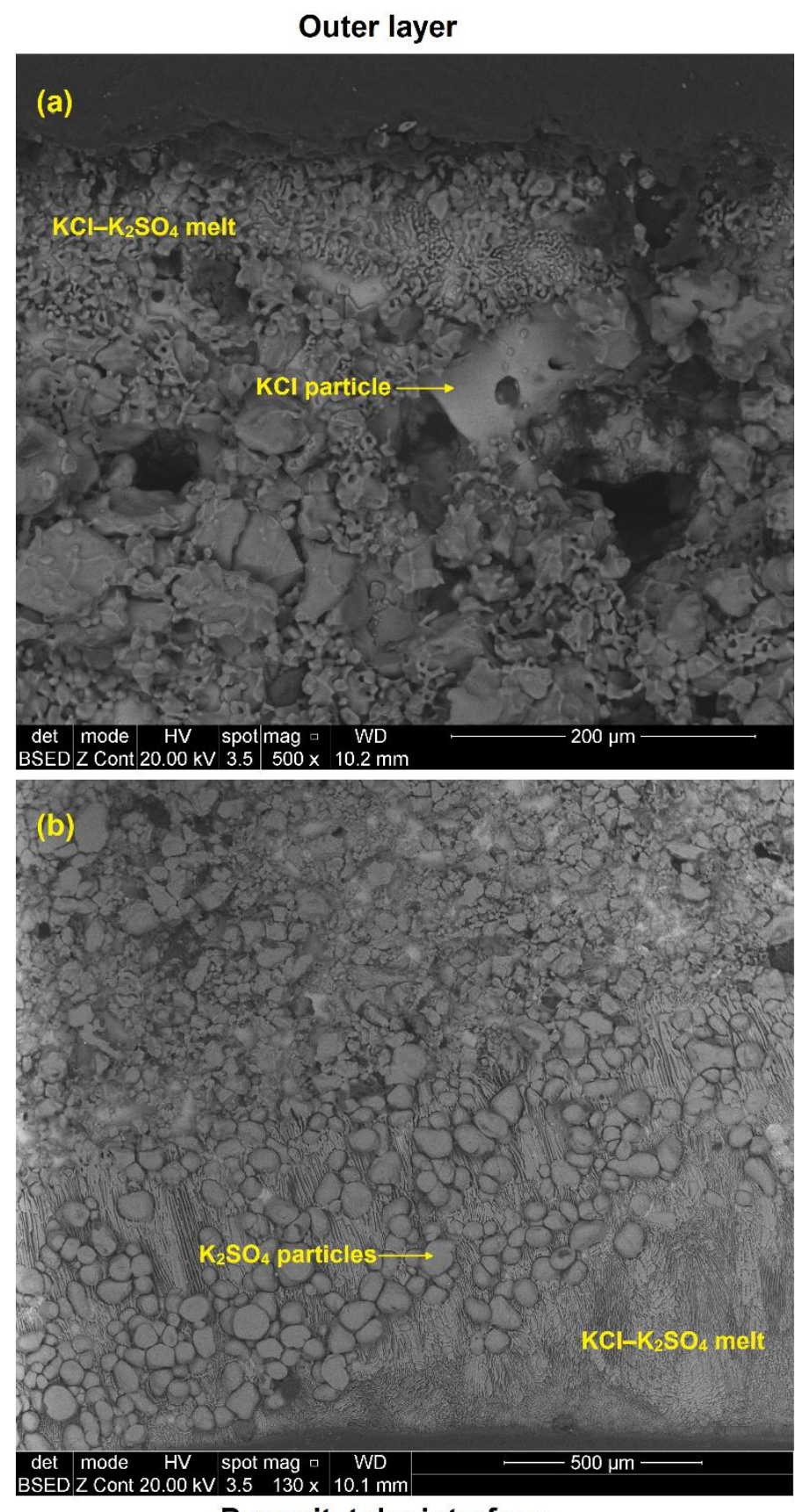

Deposit-tube interface

Figure 7. SEM image of a $\mathrm{KCl}-\mathrm{K}_{2} \mathrm{SO}_{4}(50 \mathrm{wt} \%)$ deposit, sintered with a flue gas temperature of $700{ }^{\circ} \mathrm{C}$, a steel surface temperature of $576^{\circ} \mathrm{C}$ (cooling probe temperature of $500{ }^{\circ} \mathrm{C}$ ) for $2 \mathrm{~h}$, at (a) the outer layer of the deposit, in contact with the flue gas, and at (b) the inner layer of the deposit, in contact with the superheater steel tube. 


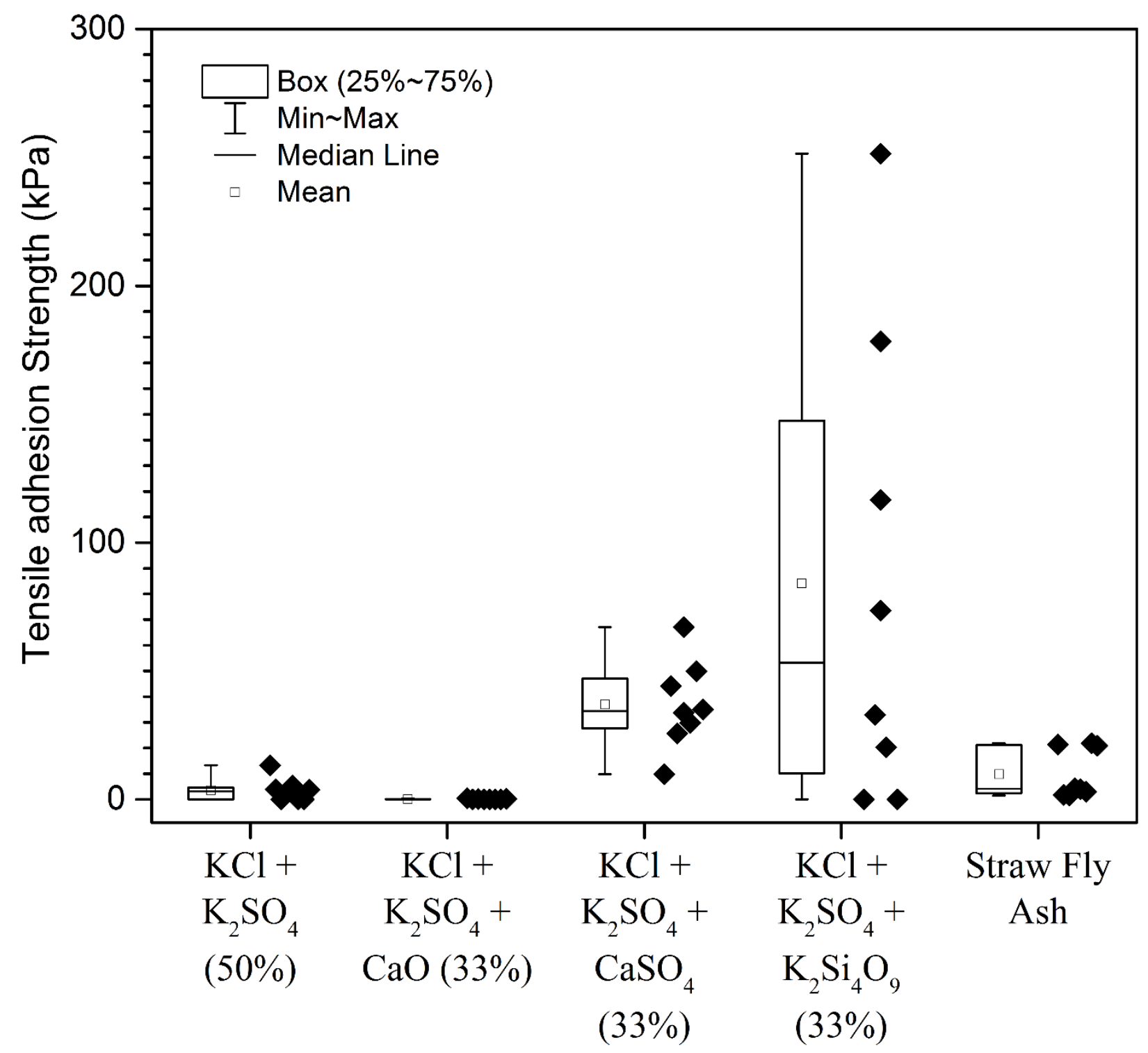

Figure 8. Effect of deposit composition on tensile adhesion strength. Deposits sintered with a flue gas temperature of $650{ }^{\circ} \mathrm{C}$, a cooling probe temperature of $500{ }^{\circ} \mathrm{C}$, and a mean steel surface temperature of $562{ }^{\circ} \mathrm{C}$ for $2 \mathrm{~h}$. Superheater steel (TP347HFG) preoxidized for $24 \mathrm{~h}$. 


\section{TABLES}

Table 1. Eutectic temperature/glass transition temperature of the investigated model deposits.

Eutectic data obtained from Janz et al. ${ }^{25}$

\begin{tabular}{|l|l|}
\hline Composition & $\begin{array}{l}\text { Eutectic } \\
\text { temperature } \\
\text { transition } \\
\text { temperature }\end{array}$ \\
& $\left({ }^{\circ} \mathbf{C}\right)$ \\
\hline $\mathrm{KCl}+\mathrm{K}_{2} \mathrm{SO}_{4}{ }^{\dagger}$ & 690 \\
\hline $\mathrm{KCl}+\mathrm{K}_{2} \mathrm{SO}_{4}+\mathrm{CaO}^{\dagger}$ & 690 \\
\hline $\mathrm{KCl}+\mathrm{K}_{2} \mathrm{SO}_{4}+\mathrm{CaSO}_{4}^{\dagger}$ & 644 \\
\hline $\mathrm{KCl}+\mathrm{K}_{2} \mathrm{SO}_{4}+\mathrm{K}_{2} \mathrm{Si}_{4} \mathrm{O}_{9}$ & 650 \\
\hline
\end{tabular}

Table 2. Composition, particle size and ash melting analysis of the investigated straw fly ash, obtained from a grate-fired boiler.

\begin{tabular}{|l|l|}
\hline Element & $\begin{array}{l}\text { Composition (wt } \\
\text { \%, dry basis) }\end{array}$ \\
\hline $\mathrm{Al}$ & -- \\
\hline $\mathrm{Ca}$ & 1.3 \\
\hline $\mathrm{Cl}$ & 19 \\
\hline $\mathrm{Fe}$ & 0.044 \\
\hline $\mathrm{K}$ & 43 \\
\hline $\mathrm{Mg}$ & 0.12 \\
\hline $\mathrm{Na}$ & 0.9 \\
\hline $\mathrm{P}$ & - \\
\hline $\mathrm{S}$ & 7.9 \\
\hline $\mathrm{Si}$ & 1.1 \\
\hline
\end{tabular}




\begin{tabular}{|l|l|}
\hline $\mathrm{Ti}$ & - \\
\hline $\mathrm{Mn}$ & 0.059 \\
\hline Deformation temperature ${ }^{27}\left({ }^{\circ} \mathrm{C}\right)$ & 640 \\
\hline $\begin{array}{l}\text { Hemispherical temperature } \\
\left({ }^{\circ} \mathrm{C}\right)\end{array}$ & 640 \\
\hline Fluid temperature ${ }^{27}\left({ }^{\circ} \mathrm{C}\right)$ & 760 \\
\hline Median particle size $(\mu \mathrm{m})$ & 51.7 \\
\hline
\end{tabular}

Table 3. Statistical analysis of data sets with varying cooling probe temperature. Two-tail Welch's t-test for unpaired data with unequal variances, $\alpha=0.05 . \mathrm{KCl}-\mathrm{K}_{2} \mathrm{SO}_{4}(50 \mathrm{wt} \%)$ deposits, sintered with a flue gas temperature of $650{ }^{\circ} \mathrm{C}$ for $2 \mathrm{~h}$.

\begin{tabular}{|c|c|c|c|c|}
\hline \multicolumn{2}{|c|}{ Compared data sets } & \multirow[t]{2}{*}{$\mathrm{T}$} & \multirow[t]{2}{*}{$\mathrm{p}=\mathrm{P}\left(|\mathrm{T}| \leq \mathrm{t}_{1-\alpha / 2, v}\right)$} & \multirow{2}{*}{$\begin{array}{l}\text { Data } \\
\text { significantly } \\
\text { different? } \\
(p \leq 0.05 ?)\end{array}$} \\
\hline $\begin{array}{l}\text { Cooling probe } \\
\text { temperature, mean } \\
\text { steel surface } \\
\text { temperature }\left({ }^{\circ} \mathrm{C}\right)\end{array}$ & $\begin{array}{l}\text { Cooling probe } \\
\text { temperature, mean } \\
\text { steel surface } \\
\text { temperature }\left({ }^{\circ} \mathrm{C}\right)\end{array}$ & & & \\
\hline 450,538 & 500,562 & -0.5281 & 0.6089 & No \\
\hline 500,562 & 600,628 & -0.7199 & 0.4881 & No \\
\hline 600,628 & 650,650 & -2.2932 & 0.0425 & Yes \\
\hline 450,538 & 650,650 & -3.9671 & 0.0019 & Yes \\
\hline
\end{tabular}

Table 4. Statistical analysis of data sets with varying flue gas temperature. Two-tail Welch's t-test for unpaired data with unequal variances, $\alpha=0.05 . \mathrm{KCl}-\mathrm{K}_{2} \mathrm{SO}_{4}(50 \mathrm{wt} \%)$ deposits, sintered with a cooling probe temperature of $500{ }^{\circ} \mathrm{C}$ for $2 \mathrm{~h}$. Mean steel surface temperatures varied from $500-$ $576^{\circ} \mathrm{C}$.

\section{Compared data sets}




\begin{tabular}{|l|l|l|l|l|}
\hline $\begin{array}{l}\text { Flue gas temperature } \\
\left({ }^{\circ} \mathrm{C}\right)\end{array}$ & $\begin{array}{l}\text { Flue gas temperature } \\
\left({ }^{\circ} \mathrm{C}\right)\end{array}$ & $\mathrm{T}$ & $\mathrm{p}=\mathrm{P}\left(|\mathrm{T}| \leq \mathrm{t}_{1-\alpha / 2, v)}\right.$ & $\begin{array}{l}\text { Data } \\
\text { significantly } \\
\text { different? } \\
(\mathbf{p} \leq \mathbf{0 . 0 5})\end{array}$ \\
\hline 500 & 550 & 1.2965 & 0.2514 & No \\
\hline 550 & 600 & -1.1280 & 0.3024 & No \\
\hline 600 & 650 & -0.3018 & 0.7684 & No \\
\hline 650 & 700 & -2.5395 & 0.0294 & Yes \\
\hline
\end{tabular}

Table 5. Statistical analysis of data sets with varying deposit composition. Two-tail Welch's t-test for unpaired data with unequal variances, $\alpha=0.05$. Deposits sintered with a flue gas temperature of $650{ }^{\circ} \mathrm{C}$, a cooling probe temperature of $500{ }^{\circ} \mathrm{C}$, and a mean steel surface temperature of $562{ }^{\circ} \mathrm{C}$ for $2 \mathrm{~h}$.

\begin{tabular}{|l|l|l|l|l|}
\hline \multicolumn{2}{|l|}{ Compared data sets } & T & $\mathrm{p}=\mathrm{P}\left(|\mathrm{T}| \leq \mathrm{t}_{1}-\alpha / 2, v\right)$ & $\begin{array}{l}\text { Data } \\
\text { significantly } \\
\text { different? } \\
(\mathrm{p} \leq \mathbf{0 . 0 5} \text { ) }\end{array}$ \\
\hline $\begin{array}{l}\text { Composition (wt } \\
\%\end{array}$ & Composition (wt \%) & & & Yes \\
\hline $\mathrm{KCl}+\mathrm{K}_{2} \mathrm{SO}_{4}(50 \%)$ & $\begin{array}{l}\mathrm{KCl}+\mathrm{K}_{2} \mathrm{SO}_{4}+\mathrm{CaO} \\
(33 \%)\end{array}$ & 6.7866 & 0.0011 & Yes \\
\hline $\begin{array}{l}\mathrm{KCl}+\mathrm{K}_{2} \mathrm{SO}_{4}+\mathrm{CaO} \\
(33 \%)\end{array}$ & $\begin{array}{l}\mathrm{KCl}+\mathrm{K}_{2} \mathrm{SO}_{4}+ \\
\mathrm{CaSO}_{4}(33 \%)\end{array}$ & -12.4072 & 0.0002 & Yes \\
\hline $\mathrm{KCl}+\mathrm{K}_{2} \mathrm{SO}_{4}(50 \%)$ & $\begin{array}{l}\mathrm{KCl}+\mathrm{K}_{2} \mathrm{SO}_{4}+ \\
\mathrm{K}_{2} \mathrm{Si}_{4} \mathrm{O}_{9}(33 \%)\end{array}$ & -5.7502 & 0.0003 & No \\
\hline $\mathrm{KCl}+\mathrm{K}_{2} \mathrm{SO}_{4}(50 \%)$ & Straw fly ash & -0.3627 & 0.7237 & \\
\hline
\end{tabular}

